\title{
一軸浮上制御磁気軸受の構造改善
}

\section{Improvement of Structure of One Axis Controlled Magnetic Bearing}

\author{
○廣瀬 健太郎, 花澤 雄太, 坂井 伸朗, 浅海 賢一, 小森 望充（九工大） \\ Kentarou HIROSE, Yuta HANAZAWA, Nobuo SAKAI, Kennichi ASAMI, Mochimitsu KOMORI \\ Kyushu Institute of Technology, Sensuicho 1-1, Tobata-ku, Kitakyushu-shi, Fukuoka
}

Key Words: flow channel, blood pump, one axis control, magnetic bearing

\section{1. 研究目的}

人工心臓への適用を想定した小型かつ単純な装置構造の 磁気軸受を提案する。提案する磁気軸受は軸流式ポンプを 想定しているため，軸方向からロータを磁気支持する構造 とする。そこで本研究では，ロー夕を磁気支持するステー 夕は, 装置の構造と制御系の簡単化のため, 内環と外環を 持つシリンダー状であり, ロータの軸方向上下を挟み込み, 軸方向の一軸のみを浮上制御する。軸流式ポンプでは一般 的に，ロータの側面にインペラがあるため側面に流路を持 つが, 本研究ではロータの中心部に流路を持つ中空軸構造 を採用する。ロータの中心部に中空軸を持たせることで, 半径方向の大きさを小さくすることを図る。また，この構 造を実現するため，ロータの中央部の流路と同径の穴を持 つセンサ及びステータを用いる。本研究では実際に提案し た磁気軸受を作製し, 回転時の動特性の評価, 検討を行う。

\section{2. 磁気軸受}

2.1 変位センサ

流路となる中空軸を持つ変位センサの回路図を Fig.1 に 示す。変位センサは, 使用温度範囲が広いことと, 回路が ブリッジ構成のため安定度が高いという利点があり, 消費 電力は $30 \mathrm{~mA}$ 以下と省電力である。Fig.2 はエアギャップを 中心位置から上下方向にそれぞれ $0.5 \mathrm{~mm}$ まで $(-0.5$ $0.5 \mathrm{~mm}$ ）変化させた時の変位センサの出力電圧を示してお り，使用範囲において出力に線形性が見られるため，実験 の使用において十分な性能が得られることがわかった。

\section{1 磁気軸受}

本研究で提案する中空軸を持つ磁気軸受の実験構成を Fig.3 に示す。Fig.3 より, 浮上回転時のロータの回転速度 と軸方向，半径方向の変位を測定するため，ロータの回転 速度はタコメータを, 軸方向変位は浮上制御用の変位セン サを, 半径方向はレーザ変位計を用いている。ロータ， ス テータは電磁軟鉄で出来ており, ロータとステータは共に 外直径が $42.5 \mathrm{~mm}$ の同径である。ロータはロータの軸方向 上下に位置するシリンダー状のステータによってプッシュ プル的に浮上制御される。下側のステータと対面するロー 夕部分の解析モデルとロータとステータの断面を Fig.4 に 示す。本研究では浮上制御に必要な電力の省電力化と浮上 コイルスペースの縮小化のため, リング状の永久磁石をス テータの内環部に設け,バイアス磁束を得ることを図った。 永久磁石の表面磁束は $322 \mathrm{mT}$ であり, 要素数は 32,704 , 節 点数は 7,340 である。ロータと変位センサ, ステータは流 路を想定した同径の中空軸を持つ。ロータ，ステータ閒の エアギャップは上下共に $0.75 \mathrm{~mm}$ である。各浮上コイルは, 直径は $0.5 \mathrm{~mm}$ で, ステータの内環と外環の間に 266 回巻で
納められている。電磁石が発生させる磁束の向きを切り替 えることで永久磁石のバイアス磁束と合わせてロータに働 く吸引力を制御する。Fig.5 (a)に浮上コイルに流れる電流が 0A の時のロータとステータを通る磁束線を, Fig.5 (b)に浮 上コイルに流れる電流を- $0.3 \mathrm{~A}$ から $0.3 \mathrm{~A}$ まで $0.1 \mathrm{~A}$ 刻みで 変化させた時の吸引力特性の磁場解析結果を示す。Fig.5 (a) より，所望の通り磁束線が内環から外環にかけて閉じてい ることが分かる。Fig.5 (b)より, 浮上コイルに流れる電流 を変化させた時, 発生する吸引力に線形性が見られる。

ロータ側には片側 4 極の永久磁石を用い，ステータ側は 片側 6 極の空芯コイルから構成されるモータにより行った。 コイル間には三つのホールセンサ設けた。ロータ側の永久 磁石とステータは同直径のため, Fig.6 (a)より互いに向き合 う構造となる。コイルには三つのホールセンサで読み取っ た值に応じた励磁パターンを $\mathrm{AD} / \mathrm{DA}$ コンバータを介して 励磁することでロータの回転を実現する。その一例を Fig.6 (b)に示す。Fig.6 (b)より，コイルの極を切り替えることで $30^{\circ}$ ずつ回転させる。コイルには各々 $0.6 \mathrm{~A}$ 程度の電流を流 している。

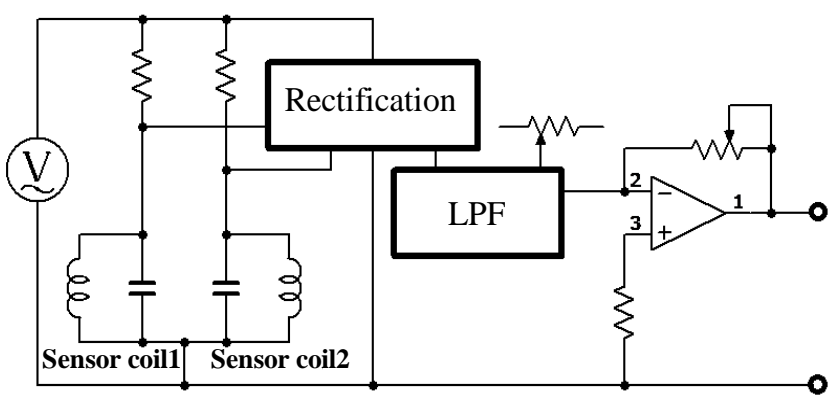

Fig.1 Circuit of displacement sensor

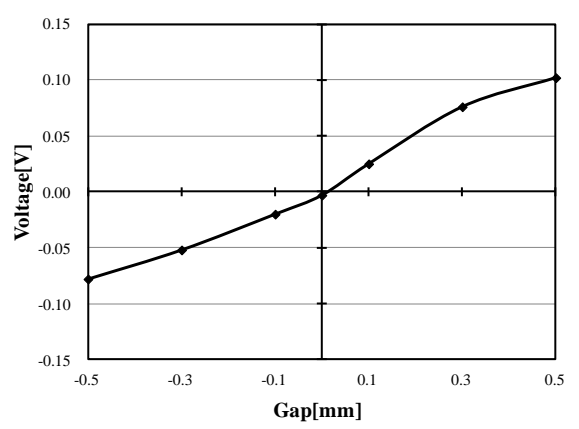

Fig.2 Relationship between output voltage of displacement sensor and gap between coil and sensor target 


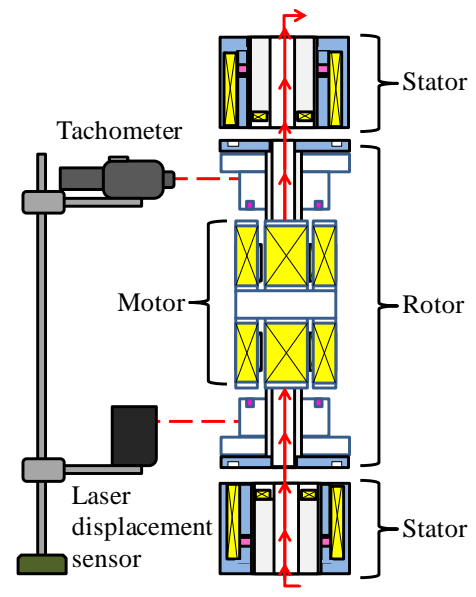

Fig.3 Experimental layout of proposal device

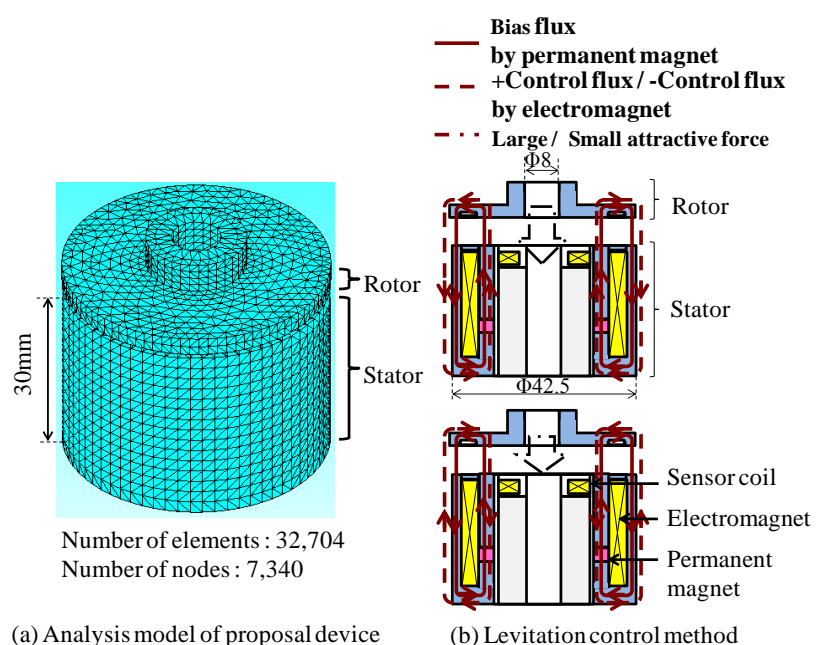

(a) Analysis model of proposal device

Fig.4 Analysis model and Levitation control

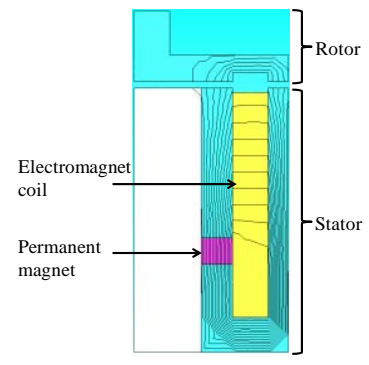

(a) Bias flux lin

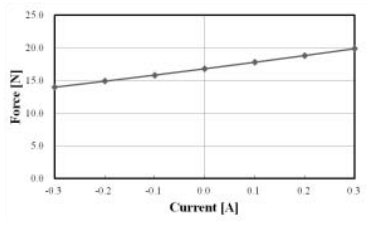

(b) Relationship between attractive force in the axial direction and current

Fig.5 Result of analysis
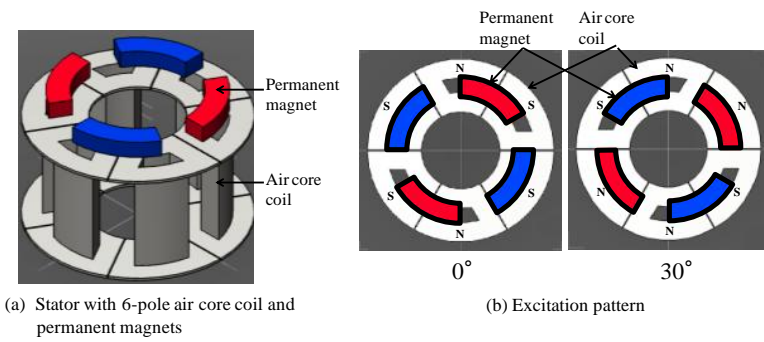

Fig.6 Driving method

\section{3. 結果と考察}

最高速回転時の実験結果を Fig.7 に示す。各空芯コイル
に $0.6 \mathrm{~A}$ 程度の電流を流し, 最大 $620 \mathrm{rpm}$ で回転することが できた。Fig.7 (a)は浮上回転時の時間に対する軸方向の変位 を示しており, 変位が $0.2 \mathrm{~mm}$ 以下と安定して浮上している ことが分かる。Fig.7 (b)は浮上回転時の時間に対する半径 方向変位を示しており, こちらも変位が小さいことが分か る。しかしながら, 軸方向の変位よりも半径方向の変位は 大きく，振れまわりの様な挙動が見られた。これは，軸方 向制御は安定しているものの, 半径方向は能動的, 受動的 支持を行っておらず，軸方向の吸引力で軸中央に吸引制御 していためと考えられる。

ロータに傾きが見られたため，ロータの傾き時の磁束密 度とトルクについて磁場解析を行った。安定浮上時の磁束 線を Fig.8 (a)に，ロータが 2.0 度傾いた時の磁束線を Fig.8 (b)に, 0 1.5 度まで傾けた時の復元トルクを Fig.8 (c)に示す。 Fig.8 (a)(b)から, 安定浮上時, 傾き時において磁束線がと じていることがわかる。Fig.8 (c)からロータが傾いた際に最 大で $0.09 \mathrm{Nm}$ 程度と十分な復元力が発生していないことが 分かる。

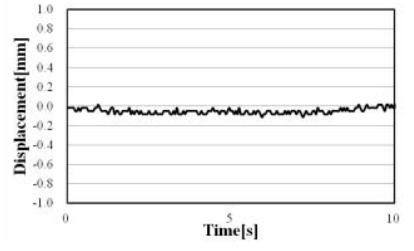

(a) Axial direction

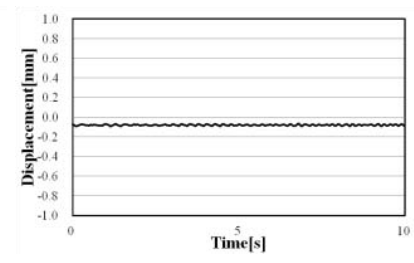

(b) Radial direction
Fig.7 Result of rotational experiment
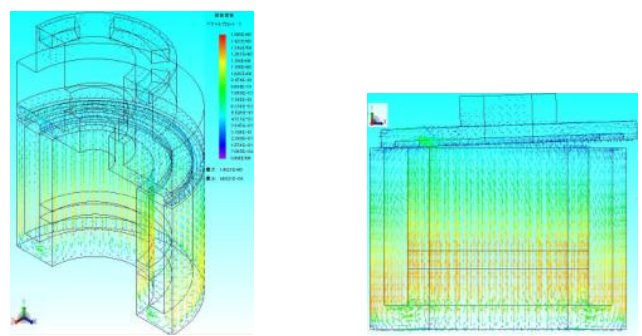

(a) Bias flux with stably levitation $\quad$ (b) Bias flux with slope of two degrees

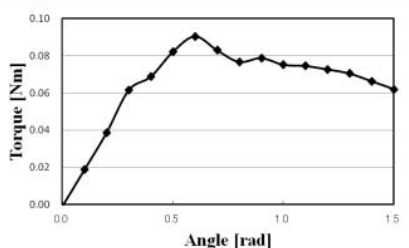

(b) Reconstruction torque

Fig.8 Consideration of reconstruction torque

\section{4. まとめ}

左心室補助型人工心臓への適用を想定したロータの軸方 向上下を永久磁石と電磁石から成るシリンダー状のステー タで挟み込み，一軸のみを浮上制御する磁気軸受の構造を 提案した。また，提案した磁気軸受は流路を想定した中空 軸を持っている。片側 4 極の永久磁石と片側 6 極の空芯コ イルを用いて，最高 620rpmで回転することができた。

しかしながら, 半径方向の変位が大きくなってしまった。 また，傾きに関して十分な復元力が得られておらず，構造 による改善や受動支持等が必要なことが分かった。今後は 半径方向変位と傾きに対する制御方法の検討と, ロータの 中空軸にインペラを取り付けて，揚程実験等を行っていき たい。 